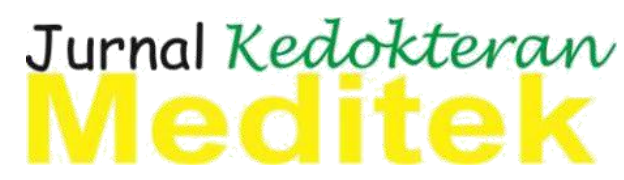

p-ISSN : 2686-1437

e-ISSN : 2686-0201

http://ejournal.ukrida.ac.id/ojs/index.php/Meditek/index

\title{
Pengaruh Incorporating Progressive Muscle Relaxation dan Diaphragm Breathing Exercise terhadap Aliran Puncak Ekspirasi Pasien Asma
}

\author{
Keristina Ajul $^{1}$, Yakobus Siswadi², Wilhelmus Hary Susilo ${ }^{3}$ \\ ${ }^{1}$ Program Studi Keperawatan Program Magister STIK Sint Carolus, Jakarta, Indonesia \\ ${ }^{2}$ Fakultas Keperawatan Universitas Pelita Harapan, Jakarta, Indonesia \\ ${ }^{3}$ Universitas Persada Indonesia YAI, Jakarta, Indonesia \\ Alamat Korespondensi: Keristina Ajul: petrifch@gmail.com
}

\begin{abstract}
Abstrak
Asma adalah suatu kelainan berupa inflamasi kronik saluran napas yang mengakibatkan penyempitan saluran napas, sehingga meningkatkan resistensi aliran udara dan menurunkan laju aliran ekspirasi. Selain terapi farmakologis, penatalaksanaan asma juga dapat dilakukan secara non farmakologis, diantaranya dengan latihan incorporating progressive muscle relaxation dan diaphragm breathing exercise yang dapat meningkatkan aliran puncak ekspirasi. Tujuan penelitian ini adalah untuk mengetahui pengaruh incorporating progressive muscle relaxation dan diaphragm breathing exercise terhadap peningkatan aliran puncak ekspirasi (APE) pasien asma. Metode penelitian adalah quasy experimental pre-test dan post-test with control group. Jumlah responden penelitian adalah 80 orang yang dibagi menjadi 2 kelompok yaitu 60 orang kelompok intervensi dan 20 orang kelompok kontrol. Hasil uji beda paired sample t-test pada kelompok intervensi menunjukkan perbedaan yang signifikan APE sebelum dan sesudah intervensi $(65,05 \%$ vs $81,17 \%, \mathrm{p}=0,00)$. Hasil uji independen t-test menunjukkan perbedaan yang signifikan APE kelompok intervensi dengan kelompok kontrol $(81,17 \%$ vs $65,10 \%, \mathrm{p}=0,00)$. Penelitian ini menyimpulkan bahwa latihan incorporating progressive muscle relaxation dan diaphragm breathing exercise berpengaruh pada peningkatan APE.
\end{abstract}

Kata kunci: Asma, aliran puncak ekspirasi, diaphragm breathing exercise, incorporating progressive muscle relaxation

\section{The Effect of Incorporating Progressive Muscle Relaxation and Diaphragm Breathing Exercise on the Peak Expiration Flow of Asthma Patients}

\begin{abstract}
Asthma is a disorder in the form of chronic inflammation of the airways, resulting in the narrowing of the airways, thereby increasing resistance to airflow and decreasing the expiratory flow rate. Asthma management is not only pharmacological but also non-pharmacological. The latter includes exercises incorporating progressive muscle relaxation and diaphragm breathing exercise which can increase peak expiratory flow. The aim of this study was to determine the effect of incorporating progressive muscle relaxation and diaphragm breathing exercise on the increase in peak expiratory flow (PEF) of asthma patients. The research method was quasy experimental pre-test and post-test with control group. The number of research respondents was 80 people, divided into 2 groups, namely 60 people in the intervention group and 20 people in the control group. The results of the paired sample t-test difference in the intervention group showed a significant difference in PEF before and after the intervention $(65.05 \%$ vs $81.17 \%, p=0.00)$. The results of the independent $t$-test showed a significant difference between the PEF of the intervention group and the control group $(81.17 \%$ vs $65.10 \%, p=0.00)$. In conclusion, incorporating progressive muscle relaxation and diaphragm breathing exercise has an effect on the improvement of PEF.
\end{abstract}

Keywords: asthma, peak expiratory flow, diaphragm breathing exercise, incorporating progressive muscle relaxation 


\section{Pendahuluan}

Asma adalah suatu kelainan berupa peradangan kronik saluran napas yang mengakibatkan penyempitan saluran napas (hiperaktifitas bronkus) sehingga menimbulkan gejala episodik berulang berupa mengi, sesak napas, dada terasa berat, dan batuk terutama pada malam atau dini hari. ${ }^{1}$ Penyakit ini terjadi pada semua golongan usia, sekitar setengah dari kasus asma terjadi pada anak-anak dan sepertiga lainnya terjadi sebelum usia 40 tahun dengan beban global untuk penyakit ini semakin meningkat., ${ }^{2,3}$ Penyakit ini merupakan masalah kesehatan di dunia, baik di negara maju maupun di negara-negara berkembang. ${ }^{4}$

Berdasarkan laporan Global Asthma Network tahun 2018, kasus asma di seluruh dunia mencapai 339 juta orang. Angka kematian tertinggi terjadi di Afrika Selatan dengan perkiraan $18,5 \%$ per 100.000 kasus asma, dan di India, prevalensi asma 8\% dari 1,31 miliar penduduk India. Di Indonesia, prevalensi asma berbeda menurut provinsi. ${ }^{4}$ Riset kesehatan dasar tahun 2018, melaporkan prevalensi asma di Indonesia adalah 2,4\%. Prevalensi asma tertinggi terdapat di Daerah Istimewa Yogyakarta (4,5\%), diikuti Kalimantan Timur (4,0\%), Bali (3,9\%), dan /Kalimantan Tengah $(3,4 \%)$. Provinsi Sumatera Selatan memiliki prevalensi asma sebesar $1,9 \% .^{5}$ Asma memberikan dampak pada disabilitas dan kematian dini pada anak usia 10-14 tahun dan orang tua usia 75-79 tahun. Saat ini, asma termasuk dalam 14 besar penyakit yang menyebabkan disabilitas di seluruh dunia. ${ }^{6}$

Pada serangan asma, pasien mengalami kesulitan bernapas, mengi saat ekspirasi, sesak napas, batuk tidak produktif, takikardi, dan takipnea. Serangan yang berat melibatkan otot pernapasan tambahan dan mengi terdengar saat inspirasi dan ekspirasi, serta memerlukan usaha untuk bernapas. Tanda usaha untuk bernapas yaitu napas cuping hidung, bernapas melalui mulut, dan penggunaan otot bantu pernapasan. Penyempitan bronkus pada penderita asma menyebabkan penurunan force expired volume in one second (FEV1), forced vital capacity (FVC) serta rasio FEV $_{1}$ dan FVC. ${ }^{7-9}$

Monitoring fungsi pernapasan penderita asma penting dilakukan untuk menilai berat ringanya asma. Salah satu pemeriksaan adalah aliran puncak ekspirasi (APE). Nilai APE dapat diperoleh melalui pemeriksaan yang sederhana yaitu menggunakan peak flow meter. ${ }^{10} \mathrm{APE}$ dipengaruhi oleh umur, jenis kelamin, indeks masa tubuh, lamanya sakit, riwayat merokok, ${ }^{11}$ allergen, latihan, polusi udara, dan penyakit refluks gastroesofageal. ${ }^{12}$ Pemeriksaan nilai APE penting untuk mendeteksi berat asma, derajat variasi diurnal, respons pengobatan saat serangan akut, deteksi perburukan, respons pengobatan jangka panjang, dan justifikasi objektif dalam memberikan pengobatan. ${ }^{10}$

Penatalaksanaan asma yang berfungsi untuk mengontrol fungsi paru terdiri dari tindakan farmakologis dan non farmakologis. ${ }^{13}$ Tindakan farmakologis untuk pilihan obat pada pasien asma terdiri dari obat pelega, obat pengontrol, dan obat tambahan. Tindakan non farmakologis yang direkomendasikan adalah penghentian merokok dan menghindari asap tembakau di lingkungan, aktivitas fisik, menghindari obat-obatan yang dapat memperburuk asma, menghindari allergen, diet sehat, penurunan berat badan untuk pasien obesitas, mengontrol kecemasan, takut dan stress, menghindari alergen luar, dan latihan pernapasan. $^{14}$

Manajemen keperawatan pasien asma adalah menilai skala dispnea, mengidentifikasi faktor pencetus serangan asma, menghindari faktor pencetus, posisi tripod dan melakukan latihan relaksasi untuk memperbaiki pernapasan selama episode asma. ${ }^{8}$ Terapi relaksasi seperti yoga, meditasi, teknik relaksasi, dan teknik pernapasan dapat membantu pasien mengendurkan otot pernapasan dan mengurangi laju pernapasan. ${ }^{12}$ Peran perawat untuk memberikan perawatan yang berkualitas dapat mengurangi angka morbiditas dan mortalitas terkait pasien asma, yaitu dengan melibatkan pasien dalam terapi dan perawatan diri. Hal ini berkontribusi pada pengobatan yang berkualitas.

Perawatan mandiri (selfcare) merupakan sebuah tindakan mengupayakan orang lain untuk mengembangkan kemampuan yang dimiliki secara maksimal, sehingga seseorang dapat mempertahankan fungsi yang optimal. Dalam teori perawatan diri, keperawatan didefinisikan sebagai suatu kegiatan praktik yang bertujuan untuk mendewasakan orang dalam memaksimalkan fungsi kesehatan yang dimilkinya. ${ }^{15}$ Salah satu peran perawat dalam manajemen pasien asma adalah melakukan tindakan supportive-educative terkait rehabilitasi paru dengan melakukan latihan relaksasi yaitu progressive muscle relaxation dan diaphragm breathing exercise.

Progressive muscle relaxation (PMR) merupakan suatu teknik relaksasi yang bertujuan untuk melatih individu membuat otot-otot tubuh relaks secara keseluruhan. ${ }^{16}$ PMR merupakan latihan yang dapat dilakukan secara mandiri dan dapat dilakukan dalam posisi duduk maupun tidur sehingga dapat dilakukan dimana saja. PMR dapat digunakan pasien untuk mengurangi ketegangan 
otot dan kecemasan yang dialami sehari-hari. PMR juga dapat menurunkan frekuensi denyut jantung, menurunkan pemakaian oksigen dan frekuensi pernapasan, meningkatkan oksigenasi dan memperbaiki ventilasi, serta meringankan sesak napas. ${ }^{17}$ Lebih lanjut, PMR membantu mengurangi permasalahan asma bronchiale. Efektivitas dari tindakan ini dapat dilihat dari adanya peningkatan aliran puncak ekspirasi, relaksasi otot, serta berkurangnya sesak napas disebabkan adanya latihan pernapasan yang digunakan dalam latihan PMR. Penggunaan latihan pernapasan dalam PMR menyebabkan terjadinya peningkatan tekanan pada rongga mulut. Tekanan ini akan diteruskan melalui cabang-cabang bronkus sehingga meningkatkan tekanan intrabronkial seimbang, memperlambat fase ekspirasi, memudahkan pengosongan udara dari rongga toraks, meningkatkan pengeluaran karbondioksida sehingga dapat mencegah air trapping dan kolaps bronkiolus pada waktu ekspirasi. ${ }^{11,18}$

Latihan pernapasan diafragma merupakan terapi latihan pernapasan untuk pasien asma yang dapat meningkatkan pengeluaran $\mathrm{CO}_{2}$ dari paru, mengurangi kerja napas, dan meningkatkan ventilasi. Peningkatan ventilasi mengakibatkan peningkatan perfusi, sehingga tekanan intraalveoli meningkat dan pertukaran gas juga menjadi efektif. Kondisi ini menurunkan derajat keasaman (pH) dan $\mathrm{CO}_{2}$ dalam arteri dan serta meningkatkan APE. ${ }^{20}$ Selain itu dampak dari latihan ini adalah untuk memelihara keseimbangan kadar imunoglobulin E (IgE) pada bronkus serta menurunkan respon yang berlebihan dari jalan napas. Dampak lain, latihan ini juga meningkatkan nilai aliran puncak ekspirasi dan menurunkan frekuensi kekambuhan asma. ${ }^{21}$ Latihan pernapasan diafragma memainkan peran penting terhadap aliran puncak ekspirasi. ${ }^{22}$

Penggabungan progressive muscle relaxation dan diaphragm breathing exercise dapat membantu otot pernapasan dalam melakukan adaptasi, terutama dalam proses biokimia di dalam otot yaitu menstimulasi saraf simpatis merangsang kelenjar endokrin, melepaskan epinefrin dan norepinefrin. ${ }^{11}$ Epinefrin berikatan dengan $\beta 2$ di jantung dan otot rangka untuk memperkuat mekanisme vasodilatorasi lokal di jaringanjaringan paru, sehingga akan terjadi bronkodilatasi dan udara akan lebih lancar untuk keluar masuk dan nilai aliran puncak ekspirasi akan dapat meningkat. ${ }^{23}$ Penelitian yang telah dilakukan oleh Georga dkk (2018) yang menggabungkan latihan progressive muscle relaxation dengan latihan pernapasan biofeedback menunjukkan peningkatan kualitas hidup, penurunan stress, penurunan keterbatasan aktivitas dan peningkatan toleransi aktivitas. ${ }^{24}$

Pendekatan untuk penggabungan progressive muscle relaxation dan diaphragm breathing exercise belum dilakukan oleh peneliti terdahulu, maka dalam penelitian ini penulis tertarik untuk menggabungkan kedua intervensi tersebut. Intervensi ini dapat dilakukan secara mandiri oleh pasien, mudah dilakukan dan tidak membutuhkan alat khusus serta tidak membutuhkan biaya.

Tujuan dari penelitian ini adalah untuk menilai pengaruh incorporating progressive muscle relaxation dan diaphragm breathing exercise terhadap aliran puncak ekspirasi pasien asma.

\section{Metodologi}

Penelitian ini merupakan jenis penelitian kuantitatif dengan desain penelitian quasy experimental; pre-test dan post-test with control group yaitu pendekatan yang dilakukan 2 kali yaitu sebelum dan sesudah eksperiment. ${ }^{25}$ Populasi dalam penelitian ini adalah semua pasien asma dewasa yang berkunjung ke poliklinik rawat jalan Charitas Hospital Km 7 Palembang sejak Oktober 2019 sampai Maret 2020. Teknik pengambilan sampel dalam penelitian ini secara random sampling. Total sampel sebesar 80 responden, 60 orang pada kelompok intervensi incorporating progressive muscle relaxation dan diaphragm breathing exercise dan 20 orang pada kelompok control. Pelaksanaan penelitian dilakukan di rumah responden.

Adapaun kriteria inklusinya adalah usia $\geq 18$ tahun, penderita asma derajad ringan dan sedang, pasien yang tinggal di Palembang, pasien yang bersedia menjadi responden sampai selesai dengan bukti menandatangani informed consent, dan tidak mengalami gangguan musculoskeletal.

Alat pengumpul data yang digunakan adalah lembar data demografi, lembar pelaksanaan latihan dan peak flow meter. Pada kelompok intervensi melakukan latihan incorporating progressive muscle relaxation dan diaphragm breathing exercise 2 kali sehari (pagi dan sore) selama 1 minggu. Pengukuran APE dilakukan sebelum intervensi pertama dan 1 hari sesudah melakukan intervensi yang terkahir. Data yang diperoleh dianalisis menggunakan analisis univariat dan uji beda. Analisis univariat digunakan untuk melihat distribusi data demografi, analisis uji beda digunakan untuk mengetahui pengaruh intervensi terhadap nilai APE. 
Hasil

1. Karakteristik Responden

Tabel 1. Distribusi Responden Berdasarkan Usia, Jenis Kelamin, IMT Pasien Asma 2020 $(\mathbf{n}=\mathbf{8 0})$

\begin{tabular}{|c|c|c|c|c|c|c|c|}
\hline \multirow[t]{2}{*}{$\mathrm{N}$} & \multirow[t]{2}{*}{ Variabel } & \multicolumn{2}{|c|}{ Kel Intervensi } & \multicolumn{2}{|c|}{ Kel Kontrol } & \multicolumn{2}{|c|}{ Total } \\
\hline & & Frekuensi & $\begin{array}{c}\text { Prosentase } \\
(\%)\end{array}$ & Frekuensi & $\begin{array}{c}\text { Prosentase } \\
(\%)\end{array}$ & Frekuensi & $\begin{array}{c}\text { Prosentase } \\
(\%)\end{array}$ \\
\hline \multirow[t]{6}{*}{1} & Usia & & & & & & \\
\hline & Masa & & & & & & \\
\hline & Dewasa & 43 & 71,7 & 13 & 65,0 & 56 & 70,0 \\
\hline & $\begin{array}{l}\text { Awal: 18-40 } \\
\text { Masa }\end{array}$ & & & & & & \\
\hline & $\begin{array}{l}\text { dewasa } \\
\text { madya: } 41- \\
60\end{array}$ & 15 & 25,0 & 4 & 20,0 & 19 & 23,8 \\
\hline & $\begin{array}{l}\text { Masa } \\
\text { dewasa } \\
\text { akhir }>60\end{array}$ & 2 & 3,3 & 3 & 15,0 & 5 & 6,2 \\
\hline \multicolumn{8}{|c|}{2} \\
\hline & $\begin{array}{l}\text { Jenis } \\
\text { kelamin }\end{array}$ & & & & & & \\
\hline & Laki-laki & 28 & 46,7 & 5 & 25,0 & 33 & 41,2 \\
\hline & Perempuan & 32 & 53,3 & 15 & 75,0 & 47 & 58,8 \\
\hline \multicolumn{8}{|l|}{3} \\
\hline & IMT & & & & & & \\
\hline & $\begin{array}{l}\text { Underweight } \\
<18.5\end{array}$ & 6 & 10,0 & 3 & 15,0 & 9 & 11,2 \\
\hline & $\begin{array}{l}\text { Normal } \\
18,5-24,9\end{array}$ & 30 & 50,0 & 12 & 60,0 & 42 & 52,5 \\
\hline & $\begin{array}{l}\text { Overweight } \\
25-29,9\end{array}$ & 20 & 33,3 & 4 & 20,0 & 24 & 30,0 \\
\hline & Obese $\geq 30$ & 4 & 6,7 & 1 & 5,0 & 5 & 6,3 \\
\hline
\end{tabular}

2. Analisis Perbedaan Mean APE Sebelum dan Sesudah Intervensi

Tabel 2. Perbedaan Mean APE Sebelum dan Sesudah Intervensi pada Kelompok Intervensi dan Kelompok Kontrol $2020(n=80)$

\begin{tabular}{cccc}
\hline Kelompok & \multicolumn{2}{c}{ Luaran Mean \pm SD } & P value \\
& APE pre & APE Post & \\
\hline Intervensi & $65,05 \pm 5,11$ & $81,17 \pm 8,43$ & 0,00 \\
Kontrol & $64,75 \pm 4,66$ & $65,10 \pm 5,35$ & 0,76 \\
\hline
\end{tabular}

3. Analisis Perbedaan Mean APE Sesudah Intervensi

Tabel 3. Perbedaan Nilai Mean APE Sesudah Intervensi antara Kelompok Intervensi dan Kontrol $2020(n=80)$

\begin{tabular}{cccc}
\hline Luaran & \multicolumn{2}{c}{ Nilai Rerata Luaran Mean \pm SD } & Pvalue \\
\cline { 2 - 3 } & $\begin{array}{c}\text { Intervensi } \\
\mathrm{n}=60\end{array}$ & $\begin{array}{c}\text { Kontrol } \\
\mathrm{n}=20\end{array}$ & \\
\hline $\mathrm{APE}$ & $81,17 \pm 8,43$ & $65,05 \pm 5,11$ & 0,00 \\
\hline
\end{tabular}




\section{Pembahasan}

Karakteristik usia responden pada Tabel 1 menunjukkan bahwa mayoritas responden berada pada kategori masa dewasa awal (18-40) tahun dan masa dewasa madya (41-60). Asma bisa terjadi pada siapa saja dan dapat timbul pada semua umur. Pada umur awal dewasa terjadi perubahan struktur pernapasan dan kekuatan otot pernapasan. Fungsi paru akan menurun sesuai bertambahnya umur. Keadaan ini disebabkan oleh terjadinya penurunan elastisitas dinding dada. Proses penuaan mengakibatkan penurunan elastisitas alveoli, penebalan kelenjar bronchial, dan penurunan kapasitas paru. Penurunan kapasitas paru disebabkan juga oleh adanya osteoporosis vertebra sehingga menurunkan fleksibilitas spinal dan peningkatan derajat kiposis. Lebih jauh osteoporosis akan meningkatkan diameter anteroposterior rongga dada. ${ }^{23}$

Karakteristik jenis kelamin responden secara keseluruhan menunjukkan bahwa mayoritas responden adalah berjenis kelamin perempuan. Perempuan juga dominan jika dilihat baik pada kelompok intervensi (53.3\%) maupun kelompok kontrol (75\%). Peningkatan angka kejadian asma pada perempuan di usia dewasa daripada laki-laki dikarenakan ukuran paru atau saluran napas pada perempuan lebih kecil dibandingkan laki-laki ${ }^{26}$ dan resiko kejadian asma pada anak laki-laki 4,5 kali lebih besar dibandingkan anak perempuan karena ukuran paru atau saluran napas laki-laki lebih kecil daripada perempuan pada saat anakanak. ${ }^{27}$

Guyton dan Hall mengatakan kekuatan otot pernapasan dan fungsi paru laki-laki lebih tinggi $20 \%$ - 25\% dibandingkan perempuan, karena ukuran anatomi paru laki-laki lebih besar dibandingkan perempuan. Selain itu aktivitas lakilaki lebih besar dibandingkan perempuan sehingga recoil dan compliance paru sudah terlatih. ${ }^{23}$ Hasil penelitian ini sejalan dengan Suranggana yang juga mengatakan bahwa prevalensi asma lebih tinggi pada perempuan daripada laki-laki. ${ }^{28}$

Karakteristik IMT responden pada Tabel 1 menunjukkan bahwa mayoritas responden berada pada kategori IMT normal dan overweight. Overweight badan dan obesitas meningkatkan risiko kejadian asma sampai 50\%, baik pada lakilaki maupun perempuan. ${ }^{26}$ Obesitas mempunyai banyak mekanisme penting dalam hal perubahan fisiologi paru dan berkaitan dengan terjadinya asma. Obesitas dapat menyebabkan penurunan sistem komplians paru, volume paru, dan diameter saluran nafas perifer yang mengakibatkan peningkatan hiper-reaktivitas saluran napas, perubahan volume darah pulmoner dan gangguan fungsi ventilasi perfusi. ${ }^{29}$

Berdasarkan Tabel 2, dalam kelompok intervensi, nilai rata-rata APE mengalami peningkatan jika dibandingkan antara pengukuran sebelum intervensi dan setelah intervensi. Dari hasil uji statistik ( $\mathrm{p}=0,00$ lebih kecil dari alpha $(0,05)$ disimpulkan adanya perbedaan yang signifikan antara rata-rata nilai APE pada pengukuran sebelum dan sesudah intervensi. Perbedaan nilai rata-rata yang signifikan ini mengindikasikan bahwa intervensi incorporating progressive muscle relaxation dan diaphragm breathing exercise meningkatkan nilai aliran puncak ekspirasi pasien asma.

Hasil penelitian ini didukung oleh penelitian yang dilakukan Wedri tahun 2018 yang melakukan penelitian tentang pengaruh latihan pernapasan diafragma terhadap aliran puncak ekspirasi menunjukkan hasil terdapat perbedaan nilai APE sebelum dan sesudah intervensi diaphragmtic breathing exercise dengan nilai $\mathrm{p}<0,05 .{ }^{22}$ Novarin dkk melakukan penelitian dengan memberikan latihan progressive muscle relaxation menunjukkan hasil terdapat pengaruh yang sangat bermakna terhadap peningkatan APE pada pasien asma dengan $\mathrm{p}$ value $=0,000 .{ }^{11}$ Penelitian ini juga didukung oleh Fajar dan Krisnawati tahun 2017 yang memberikan latihan relaksasi otot progresif. Hasil penelitian menunjukkan terdapat pengaruh yang signifikan antara kekambuhan tingkat asma bronkial sebelum dan sesudah pemberian latihan dengan $\mathrm{p}$ value $=0,00{ }^{30}$

Mekanisme kerja latihan latihan otot progresif yang digabungkan dalam latihan pernapasan ini menyebabkan peningkatan tekanan pada rongga mulut. Tekanan ini kemudian diteruskan melalui cabang-cabang bronkus sehingga akan meningkatkan tekanan intrabronkial (dengan mempertahankan bronkus dalam keadaan terbuka) agar seimbang atau sama dengan tekanan intraalveolar. Keadaan ini juga akan memperlama fase ekspirasi, mempermudah pengosongan udara dari rongga toraks, dan mempermudah pengeluaran karbondioksida, sehingga dapat mencegah air trapping dan kolaps bronkiolus pada waktu ekspirasi. ${ }^{11}$

Tabel 3 memperlihatkan hasil analisis dari nilai rerata APE setelah intervensi pada kelompok kontrol dibandingkan dengan kelompok intervensi. Terjadi peningkatan APE yang bermakna pada kelompok intervensi dibandingkan dengan kelompok kontrol $(\mathrm{p}=0,00, \mathrm{p}<0,05)$. Hasil ini menyimpulkan bahwa ada perbedaan yang signifikan antara kelompok intervensi incorporating progressive muscle rerlaxation dan diaphragm breathing exercise dengan kelompok 
kontrol. Perubahan aliran puncak ekspirasi sesudah dilakukan intervensi disebabkan oleh adaptasi otototot pernapasan. Gabungan dari latihan otot progresif dan latihan pernapasan akan dapat membantu otot pernapasan dalam melakukan adaptasi, terutama dalam proses biokimia di dalam otot. ${ }^{11}$

Aktivitas ringan dapat menstimulasi saraf simpatis yang dapat merangsang kelenjar endokrin untuk mengeluarkan epinefrin dan nonepinefrin. Selama berjalannya aktivitas simpatis, epinefrin berikatan dengan $\beta 2$ di jantung dan otot rangka sehingga memperkuat mekanisme vasodilatorasi lokal di jaringan-jaringan paru. Hal ini mengakibatkan terjadinya bronkodilatasi sehingga udara akan lebih lancar untuk keluar masuk dan nilai aliran puncak ekspirasi akan dapat meningkat. ${ }^{23}$

Hasil rerata kenaikan aliran puncak ekspirasi setelah dilakukan intervensi incorporating progressive muscle rerlaxation dan diaphragm breathing exercise adalah sebesar $16,12 \%$ pada kelompok intervensi. Sedangkan pada kelompok kontrol, hanya sebesar $0,35 \%$ artinya tidak terjadi perubahan yang bermakna pada kelompok kontrol. Terjadinya peningkatan APE tersebut mencerminkan bahwa terdapat peningkatan relaksasi otot pernapasan, perbaikan ventilasi alveoli untuk memperbaiki pertukaran gas dan pengaturan frekuensi pernapasan serta pola napas sehingga mengurangi air trapping. ${ }^{2}$

\section{Simpulan}

Penelitian ini menunjukkan bahwa ada perbedaan yang signifikan nilai aliran puncak ekspirasi sebelum dan sesudah diberikan latihan incorporating progressive muscle rerlaxation dan diaphragm breathing exercise ( $\mathrm{p}$ value $0,00<0,05$ ). Berdasarkan hasil penelitian ini sangat disarankan kepada pelayanan keperawatan untuk dapat memberikan intervensi ini sebagai intervensi mandiri kepada pasien asma ringan sedang sehingga dapat meningkatkan nilai aliran puncak ekspirasi.

\section{Daftar Pustaka}

1. Kemenkes RI. Buku pintar kader Posbindu. Buku Pintar Kader Posbindu. Jakarta; 2019.

2. Smeltzer, CS \& Bare B. Buku ajar keperawatan medikal bedah. Jakarta: EGC; 2010.

3. Sundaru H, Sukamto. Ilmu penyakit dalam: Asma bronkial. 6th ed. Setiati S, Alwi I, Sudoyo AW, Simadibrata M, Setiyohadi B, Syam AF, editors. Jakarta: Interna publishing; Pusat Penerbitan Ilmu Penyakit Dalam; 2014.
4. Global Asthma Network. The global asthma report 2018 [Internet]. Auckland, New Zealand; 2018. Available from: www.globalasthmanetwork.org

5. Riskesdas. Hasil utama RISKESDAS 2018. Jakarta; 2018.

6. Kemenkes RI. Asma penting diwaspadai (Never too early, never too late). Direktorat Jenderal Pelayanan Kesehatan [Internet]. 2018; Available from: http://yankes.kemkes.go.id/read-asmapenting-diwaspadai-never-too-early-nevertoo-late-4209.html

7. Huether SE, Mccance KL. Buku ajar patofisiologi. edisi Indo. Soeatmadji DW, Ratnawati R, Sujuti H, editors. singapore: Elsevier; 2019.

8. Black JM, Hawks HJ. Keperawatan medikal bedah managemen klinisuntuk hasil yang diharapkan. 8th ed. Suslia NA, Faqihani ganiajri S, Ns Peni Puji Lestari S, Retno ulan Arum Sari AK, editors. Singapore: Elsevier (Singapore); 2014.

9. Santoso FM, Harmayetty, Bakar A. Perbandingan latihan napas buteyko dan upper body exercise terhadap arus puncak ekspirasi pada pasien dengan asma bronkial. Crit Medical, Surg Nurs J 22. 2014;2:91-8.

10. PDPI. ASMA: Pedoman diagnosis dan penatalaksanaan di Indonesia. Perhimpunan Dokter Paru Indonesia. Jakarta; 2010.

11. Novarin C, Widayati N, Murtaqib. Pengaruh progressive muscle relaxation terhadap aliran puncak klien dengan asma. e-Jurnal Pustaka Kesehat. 2015;3(2):311-8.

12. Lewis SL, Dirksen SR, Heitkemper MM, Bucher L. Medical surgical nursing. ninth. Harding MM, editor. St. Louis, Missouri: Elsevier Mosby; 2014. 1-1830 p.

13. Global Initiative for Asthma. Pocket guide for asthma management and prevention: GINA executive summary. 2018;28. Available from: www.ginasthma.org

14. Global Initiative For Asthma. Global initiative for asthma: Asthma management and prevention, 2019. Pract Nurse. 2019;49(5).

15. Alligood MR. Pakar Teori keperawatan dan karya mereka. Hamid Achir Yani, editor. Singapura: Elsevier singapore Pte Ltd; 2017.

16. Soewondo S, Menaldi A, Hanum L. Stres, manajemen stres, dan relaksasi progresif. Jakarta: Lembaga Pengembangan Sarana Pengukuran dan Pendidikan Psikologi Universitas Indonesia; 2017.

17. Julianti HP, Wahyudati S, Kartadinata RT, Handoyo R, Noviolita. Efek latihan relaksasi 
otot progresif terhadap perbaikan gejala klinis, kecemasan, hasil elektromiografi dan kualitas hidup pasien spasmofilia. Media Med Muda. 2018;2 (1)(Januari-April 2017).

18. Mustafa R, Nahdliyyah AI. Penatalaksanaan fisioterapi pada kondisi asma bronchiale dengan modalitas infra merah, chest fisioterapi dan latihan progressive muscle relaxation di bbkpm surakarta. Pena J Ilmu Pengetah dan Teknol. 2019;33(1):22-8.

19. Nickel C, Kettler C, Muehlbacher M, Lahmann C, Tritt K, Fartacek R, et al. Effect of progressive muscle relaxation in adolescent female bronchial asthma patients: A randomized, double-blind, controlled study. J Psychosom Res. 2005;59(6):393-8.

20. Muttaqin A. Buku ajar asuhan keperawatan klien dengan gangguan sistem pernapasan. Jakarta: Salemba Medika; 2012.

21. Kartikasari D, Jenie IM, Primanda Y. Latihan pernapasan diafragma meningkatkan arus puncak ekspirasi (ape) dan menurunkan frekuensi kekambuhan pasien asma. J Keperawatan Indones. 2019;22(1):53-64.

22. Wedri NM, Yasa IDPGP, Sulisnadewi NLK, Sipahutar IE, Lestari AS, Hendrajaya K. Effect of diaphragmatic breathing exercise on peak expiratory flow (PEF) in individual with Asthma. Indian J Public Heal Res Dev. 2018;9(5):429-32.

23. Guyton AC, Hall JE. Buku ajar fisiologi kedokteran. Jakarta: EGC; 2014.
24. Georga G, Chrousos G, Artemiadis A, Panagiotis PP, Bakakos P, Darviri C. The effect of stress management incorporating progressive muscle relaxation and biofeedback-assisted relaxation breathing on patients with asthma: a randomised controlled trial. Adv Integr Med [Internet]. 2018;1-5. Available from: https://doi.org/10.1016/j.aimed.2018.09.001

25. Arikunto S. Prosedur penelitian suatu pendekatan praktik. Jakarta: Rineka Cipta; 2010.

26. Ikawati Z. Penatalaksanaan terapi penyakit sistem pernapasan. Yogyakarta: Bursa Ilmu; 2016.

27. Mangguang MD. Faktor risiko kejadian asma pada anak di kota Padang. Arc Com Heal. 2016;3(1):1-7.

28. Suranggana LT, Koesbaryanto, Khoiriyati A. Pengaruh senam asma bronkhial terhadap frekuensi kekambuhan pasien asma bronkhial di Puskesmas Penujak Lombok Tengah Nusa Tenggara Barat. Din Kesehat. 2018;9(5):6279.

29. Andayani N. Hubungan obesitas terhadap asma. J Kedokt Syiah Kuala. 2017;17(1):549.

30. Fajar B, Kristianawati. Pengaruh latihan relaksasi progresif untuk mencegah kekambuhan asma bronkial. IJONHS. 2017;2(1). 